\title{
PENGARUH LINGKUNGAN KERJA DAN KEPUASAN KERJA TERHADAP KINERJA DIMEDIASI MOTIVASI KERJA PADA GURU- GURU SMK MA'ARIF COMAL PEMALANG
}

\author{
Oleh :
}

\author{
Samtono \\ Dosen STIEPARI Semarang
}

\begin{abstract}
This study as to determine the effect work environment, job satisfaction, on work motivation, and its impac ton teacher ferformance in teacher's performance SMK Ma'arif Comal Pemalang

Data were obtained through a questionare. The sample used in the study were 95 respondents. The data obtained were processed using descriptive analysis and quantitative statistical anaylisis. Quantitative analysis using mutiple regression analysis to determine the effect of independent variables on the dependent variable, bu t before the tes $t$ is done first tested the validity and reliability testing.

Regression analysis showed that work environment, job satisfaction, and work motivation not affect the performance SMK Ma'arif Comal Pemalang.
\end{abstract}

Keywords : Work environment, job satisfaction, work motivation, performance

\section{PENDAHULUAN}

Kemajuan pendidikan disuatu sekolah banyak faktor memepengaruhi, disini penulis mencoba untuk meneliti dari faktor yang tersebut diatas yaitu lingkungan kerja. Karena lingkungan kerja menunjuk pada hal-hal yang berada di sekeliling dan melingkupi kerja para guru disekolah. Kondisi lingkungan kerja lebih banyak tergantung dan diciptakan oleh pimpinan dan anggota itu sendiri. Lingkungan kerja dalam perusahaan, dapat berupa : Struktur tugas, desain pekerjaan, pola kepemimpinan, pola kerjasama, ketersediaan sarana kerja, dan imbalan (reward system).

Tugas pokok dan fungsi bagi guru sudah jelas diatur dalam Undang Undang Republik Indonesia Nomor 14 Tahun 2005 tentang Guru dan Dosen, serta Peraturan Pemerintah Nomor 74 tahun 2007 tentang Guru. Adapun yang melatarbelakangi beberapa permasalahan yang ada di SMK Ma'arif Comal Pemalang antara lain adalah: Jumlah sarana dan prasarana kerja yang ada di sekolah relative belum sepadan dengan 
jumlah peserta didik yang ada, selain itu juga banyaknya jumlah peserta didik dan banyaknya guru serta tenaga kependidikan ,menjadikan lingkungan kerja menjadi kurang nyaman dan cenderung memunculkan banyak ragam permasalahan. Dengan banyaknya permasalahan yang ada disekolah membuat banyak guru merasa tidak mendapatkan kepuasan didalam bekerja, misalnya gaji yang diterima bagi guru yayasan masih relatif kecil jika dibandingkan dengan guru-guru negeri yang diperbantukan pada SMK Ma,arif, begitu pula bagi guru yang belum mendapatkan tunjangan serttifikasi guru pendapatannya jauh lebih sedikit dibandungkan guru yang sudah mendapatkan tunjangan sertifikasi. Selanjutnya pengembangan karir disekolah swasta yang tidak jelas dan tidak terpola dengan baik membuat banyak guru yang tidak puas dalam bekerja serta tidak jelasnya tupoksi dari masing-masing pembantu pimpinan sampai kesub-sub pimpinani yang masih terjadi overlapping. Berkaitan dengan hal tersebut dijumpai beberapa oaang guru yang tidak punya motivasi didalam melaksanakan pembelajaran dan kurang menunjukkan kesungguhan didalam bekerja misalnya pada saat jam pelajaran sudah dimulai masih ada beberapa guru yang datang terlambat masuk kelas.

Ada pula guru didalam melaksanakan pembelajaran belum menggunakan pakaian werfark atau seragam praktek yang sudah ditentukan yang lazim dinamakan SOP (Standar Operasional Prosedur). Dari beeberapa uraian tersebut diatas dapat diambil garis besarnya bahwa belum semuanya menunjukkan kinerja seperti yang diharapkan sesuai dengan Permendiknas Nomor 41 Tahun 2007 Tentang Penilaian Kinerja Guru. Sebagai contoh belum semua guru dalam melaksanaan pembelajaran membuat perencanaan dengan baik, dan belum semua guru dalam memberikan tugastugas atau ulangan-ulangan tidak semua dikoreksi dan hasilnya tidak diberikan pada siswa/peserta didik, mana yang salah dan mana yang sudah benar kadang-kadang siswa tidak mengerti. Masih juga dijumpai beberapa siswa yang dalam ulangan harian belum mencapai Batas Tuntas sampai menghadapai ulangan selanjutnya belum diberikan bantuan remedi. Sehingga siswa menjadi tertinggal dengan teman-teman yang lain. Banyaknya jumlah peserta didik dan banyaknya guru serta tenaga kependidikan ,menjadikan lingkungan kerja menjadi kurang nyaman dan cenderung memunculkan banyak ragam permasalahan 


\section{RUMUSAN MASALAH}

Berdasarkan masalah yang teridentifikasi, maka dapat dirumuskan masalah dalam penelitian ini adalah sebagai berikut.

1. Bagaimana lingkungan kerja berpengaruh terhadap motivasi kerja bagi guruguru SMK Ma’arif Comal Pemalang?

2. Bagaimana Kepuasan kerja berpengaruh terhadap motivasi kerja bagi guru-guru SMK Ma'arif Comal Pemalang?

3. Bagaimanakah motivasi kerja berpengaruh terhadap kinerja guru-guru SMK Ma,arif Comal Pemalang ?

4. Bagaimana lingkungan kerja berpengaruh terhadap kinerja guru-guru SMK Ma,arif Comal Pemalang?

5. Bagaimana kepuasan kerja berpengaruh terhadap kinerja guru-guru SMK Ma,arif Comal Pemalang?

6. Apakah motivasi kerja memediasi lingkungan kerja terhadap kinerja guru-guru SMK Ma'arif Comal Pemalang?

7. Apakah motivasi kerja memediasi kepuasan kerja terhadap kinerja guru-guru SMK Ma,arif Comal Pemalang?

\section{TUJUAN PENELITIAN}

Berdasarkan rumusan masalah tersebut diatas maka tujuan penelitian disisni yaitu untuk :

1. Menganalisis dan menjelaskan pengaruh lingkungan kerja terhadap motivasi kerja bagi guru-guru SMK Ma,arif Comal Pemalang

2. Menganlisis dan menjelaskan pengaruh kepuasan kerja terhadap motivasi kerja bagi guru-guru SMK Ma,arif Comal Pemalang

3. Menganalisis dan menjelaskan pengaruh motivasi kerja terhadap kinerja guruguru SMK Ma,arif Comal Pemalang

4. Menganalisis dan menjelaskan pengaruh lingkungan kerja terhadap kinerja bagi guru-guru SMK Ma,arif Comal Pemalang

5. Menganalisis dan menjelaskan pengaruh lingkungan kerja terhadap kinerja guru-guru SMK Ma,arif Comal Pemalang. 
6. Menganalisis dan menjelaskan apakah motivasi memediasi pengarud lingkungan kerja terhadap kinerja guru-guru SMK Ma,arif Comal Pemalang.

7. Menanalisis dan menjelaskan, apakah motivasi memediasi kepuasan kerja terhadap kinerja guru-guru SMK Ma,arif Comal Pemalang.

\section{LANDASAN TEORITIS}

\section{Lingkungan Kerja}

Sihombing (2009) menyatakan bahwa lingkungan kerja adalah faktor-faktor di luar manusia baik fisik maupun non fisik dalam suatu organisasi. Faktor fisik ini mencakup peralatan kerja, suhu tempat kerja, kesesakan dan kepadatan, kebisingan, luas ruang kerja sedangkan non fisik mencakup hubungan kerja yang terbentuk di instansi antara atasan dan bawahan serta antara sesama karyawan. Lingkungan kerja yang mendukung produktivitas kerja akan menimbulkan kepuasan kerja bagi pekerja dalam suatu organisasi. Selanjutnya Nitiseminto (2011) menjelaskan lingkungan kerja adalah segala sesuatu yang ada di sekitar para pekerja dan yang dapat mempengaruhi dirinya dalam menjalankan tugas-tugas yang di bebankan kepadanya. Sebuah organisasi atau organisasi bisnis yang beroperasi di sebuah lingkungan tidak dapat menafikan bahwa, selain kegiatan bisnis yang di kelolanya, mereka tersebut juga terlibat di lingkungan seputar organisasi, oleh karena itu sebuah organisasi perlu memahami lingkungan apa saja yang terkait langsung maupun tidak langsung dalam kegiatan organisasi.

\section{Kepuasan Kerja}

Menurut Robbins (2010), kepuasan kerja merupakan suatu sikap umum terhadap pekerjaan seseorang, selisih antara banyaknya ganjaran yang diterima seorang pegawai dan banyaknya yang mereka yakini dan apa yang seharusnya mereka terima. Orang yang memiliki tingkat kepuasan kerja yang tinggi akan mempunyai sikap yang positif terhadap pekerjaannya, sedangkan orang yang tidak puas dengan pekerjaannya akan mempunyai sikap yang negatif pula terhadap pekerjaannya.

Davis (2009) menyatakan kepuasan kerja adalah kepuasan pegawai terhadap pekerjaannya antara apa yang diharapkan pegawai dari pekerjaan/ kantornya. 
Kepuasan kerja adalah keadaan emosional yang menyenangkan dimana para karyawan memandang pekerjaan mereka. Kepuasan kerja mencerminkan perasaan seseorang terhadap pekerjaannya. Ini nampak dari sikap karyawan terhadap pekerjaan dan segala sesuatu di lingkungan kerjanya (As'ad, 2009).

Selanjutnya Azeem (2010) faktor-fakor yang mempengaruhi kepuasan kerja pegawai meliputi lima aspek yaitu: pekerjaan itu sendiri; gaji; pengawasan; kesempatan promosi; dan hubungan dengan sesama pekerja.

\section{Motivasi Kerja}

Menurut As'ad (2009) motivasi kerja didefinisikan sebagai sesuatu yang menimbulkan semangat atau dorongan kerja, lazim motivasi biasa disebut sebagai pendorong atau semangat kerja. Sedangkan menurut Natawijaya (2009), jenis motivasi dibedakan menjadi dua macam yaitu:

1. Motivasi intrinsik adalah motivasi yang muncul karena faktor yang berasal dari dalam dirinya. Karakteristik dari motivasi intrinsik yaitu :
a. tingkah laku (tindakan tidak ditentukan oleh ada tidaknya reward;
b. senantiasa memiliki self reinforcement;
c. memilki persepsi diri terhadap tingkah lakunya;
d. meningkatkan atau menggali motivasi.

2. Motivasi ekstrinsik adalah motivasi yang muncul karena faktor yang berasal dari luar dirinya. Karakteristik dari motivasi ekstrinsik yaitu :
a. tingkah laku (tindakan ditentukan oleh rewards);
b. tidak memiliki reinforcement;
c. tidak (kurang mempunyai persepsi diri atas tingkah lakunya dan;
d. tidak adanya upaya untuk meningkatkan motivasi kalau tidak jelas rewards nya.




\section{Kinerja Guru}

Menurut Umam ( 2010 ), kinerja adalah catatan mengenai akibat-akibat yang dihasilkan pada sebuah fungsi pekerjaan atau aktivitas selama periode tertentu yang berhubungan dengan tujuan organisasi. Selanjutnya Permendiknas Nomor 41 Tahun 2007, menjelaskan Indikator penilaian terhadap kinerja guru dilakukan terhadap tiga kegiatan dikelas yaitu: a. Perencanaan Program Kegiatan Pembelajaran, b. Pelaksanaan Kegiatan Pembelajaran, c. Pelaksanaan Evaluasi/Penilaian Pembelajaran. Dari pengertian tersebut diatas dapat disimpulkan bahwa kinerja guru adalah hasil kerja yang dicapai seseorang, dimana dilaksanakan atas tugas dan tanggung jawabnya masing-masing sesuai dengan keahliannya untuk bersama-sama memajukan organisasi dan tidak melanggar ketentuan hukum serta etika didalam pelaksanaannya, kinerja juga merupakan semua perilaku sebagai ungkapan kemampuan yang didasari oleh pengetahuan (knowledge), sikap (attitude), dan ketrampilan (skill)

\section{Kerangka Pemikiran Teorities}

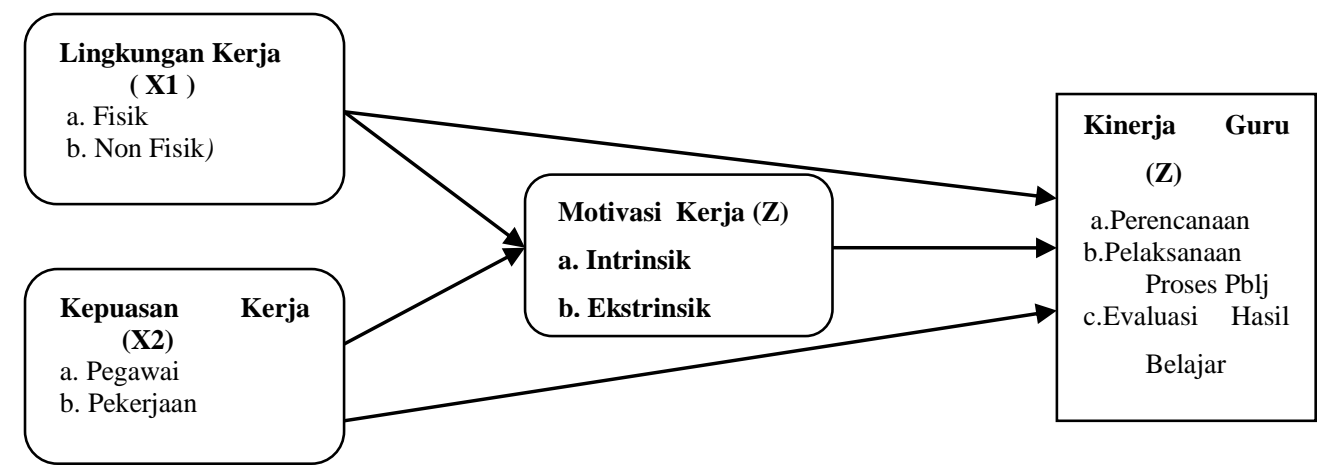

Gambar 1. Kerangka Pemikiran Teorities

\section{Hipotesis Penelitian}

Berdasarkan rumusan masalah dan tujuan penelitian tersebut di atas, maka diajukan Rumusan Hipotesis sebagai berikut :

1. Terdapat pengaruh positif dan siqnifikan lingkungan kerja terhadap motivasi kerja guru SMK Ma'arif Comal Pemalang

2. Terdapat pengaruh yang positif dan siqnifikan kepuasan kerja terhadap motivasi kerja guru SMK Ma'arif Comal Pemalang 
3. Terdapat pengaruh yang positif dan siqnifikan motivasi kerja terhadap kinerja guru SMK Ma'arif Comal Pemalang

4. Terdapat pengaruh yang positif dan siqnifikan lingkungan kerja terhadap kinerja guru SMK Ma'arif Comal Pemalang.

5. Terdapat pengaruh yang posistif dan siqnifikan kepuasan kerja terhadap kinerja guru SMK Ma'arif Comal Pemalang

6. Motivasi kerja memediasi ligkungan kerja terhadap kinerja guru SMK Ma'arif Comal Pemalang

7. Motivasi kerja memediasi kepuasan kerja terhadap kinerja guru SMK Ma'arif Comal Pemalang

\section{METODE PENELITIAN}

\section{Populasi dan Sampel}

Teknik pengambilan sampel digunakan teknik sensus, artinya semua anggota populasi diambil untuk dijadikan sampel seluruhnya Arikunto ( 2010 ). Dalam penelitian disini penulis mengambil sampel sebanyak 96 orang guru SMK Ma'arif Comal Pemalang, baik kelompok guru normatife, guru adaptif, guru produktif maupun guru ekstrakurikuler, kecuali Kepala Sekolah yang tidak dipilih menjadi sampel dalam penelitian.

\section{Teknik Analisis Data}

\section{Analisis Regresi}

Digunakan untuk melihat bagaimana pengaruh dari variabel bebas terhadap variabel tidak bebas. Dalam penelitian ini analisis regresi dilakukan dengan dua cara yang pertama merupakan regresi langsung (untuk menganalisis pengaruh lingkungan kerja dan Kepuasan Kerja terhadap motivasi kerja) dan yang kedua adalah analisis regresi dengan variabel mediasi yang dilakukan dengan tujuan untuk menganalisis lingkungan kerja dan kepuasan kerja terhadap kinerja yang dimediasi motivasi kerja.

$$
\begin{aligned}
& \text { Model Matematis: } \\
& Y=\beta_{1} X_{1}+\beta_{2} X_{2}+e_{1} \\
& Z=\beta_{3} X_{1}+\beta_{4} X_{2}+\beta_{5} Y+e_{2}
\end{aligned}
$$




\section{Uji Koefisien Determinasi (Uji $\mathbf{R}^{2}$ )}

Koefisien determinasi (Adjusted $R$ Square) digunakan untuk mengetahui seberapa besar prosentase yang mampu dijelaskan oleh variabel lingkungan kerja dan budaya organisasi terhadap kinerja dengan dimediasi motivasi kerja. Jika Adjusted $R$ Square yang diperoleh dari hasil perhitungan menunjukkan semakin besar (mendekati satu) maka dapat dikatakan bahwa sumbangan variabel bebas terhadap variabel terikat semakin besar sehingga model yang digunakan semakin besar untuk menerangkan variabel terikat. Sebaliknya jika Adjusted $R$ Square menunjukkan semakin kecil, maka model yang digunakan semakin lemah untuk menerangkan variabel terikat. Secara umum dikatakan bahwa besarnya koefisien determinasi (Adjusted R Square) berada antara 0 dan 1 atau $0 \leq$ Adjusted R Square $\leq 1$.

\section{Uji t (Parsial)}

Uji t pada dasarnya menunjukkan seberapa jauh pengaruh satu variabel independen secara individual dalam menerangkan variasi variabel dependen. Pengujian melalui uji t dilakukan dengan membandingkan $\mathrm{t}$ hitung dengan $\mathrm{t}$ tabel pada alpha $=5 \%(0,05)$.

\section{Uji F}

Uji F-statistik digunakan untuk menguji besarnya pengaruh dari seluruh variabel independen secara bersama-sama (simultan) terhadap variabel dependen. Pembuktian dilakukan dengan cara membandingkan nilai $\mathrm{F}$ kritis ( $\left.\mathrm{F}_{\text {tabel }}\right)$ dengan nilai Fhitung yang terdapat pada tabel analysis of variance.

\section{Uji Mediating atau Intervening}

Untuk mengetahui efek mediasi dari suatu variabel intervening digunakan Analisis Jalur atau Path Analysis. Variabel intervening merupakan variabel antara atau mediating, yang fungsinya untuk memediasi hubungan antara variabel independen dengan variabel dependen. Analisis Jalur merupakan perluasan dari analisis regresi berganda.

Analisis Jalur adalah penggunaan analisis regresi untuk menaksir hubungan kausalitas antar variabel yang telah ditetapkan sebelumnya berdasarkan teori. Apa yang dapat dilakukan oleh Analisis Jalur adalah menentukan pola 
hubungan antara 3 atau lebih variabel dan tidak dapat digunakan untuk menkonfirmasi atau menolak hipotesis kausalitas imajiner (Ghozali, 2005).

Definisi Konsep dan Operasional

Tabel 1

Definisi Konsep dan Operasional

\begin{tabular}{|c|c|c|c|c|c|}
\hline \multirow{2}{*}{ NO. } & \multirow{2}{*}{ Variabel } & \multirow{2}{*}{ Definisi Konsep } & \multicolumn{2}{|c|}{ Operasional } & \multirow{2}{*}{ Pengukuran } \\
\hline & & & Dimensi & Indikator & \\
\hline 1. & $\begin{array}{l}\text { Lingkungan } \\
\text { Kerja }\end{array}$ & $\begin{array}{l}\text { Lingkungan kerja } \\
\text { adalah segala } \\
\text { sesuatu yang ada di } \\
\text { sekitar para pekerja } \\
\text { dan dapat } \\
\text { mempengaruhi } \\
\text { dirinya dalam } \\
\text { menjalankan tugas } \\
\text { yang di bebankan } \\
\text { (Nitisemito 2002) }\end{array}$ & $\begin{array}{l}\text { a. Tata ruang } \\
\text { yang tepat } \\
\text { b. Pencahayaan } \\
\text { memadai } \\
\text { c. Drainase dan } \\
\text { ventilasi } \\
\text { yang baik } \\
\text { d. Pengaturan } \\
\text { ruang }\end{array}$ & 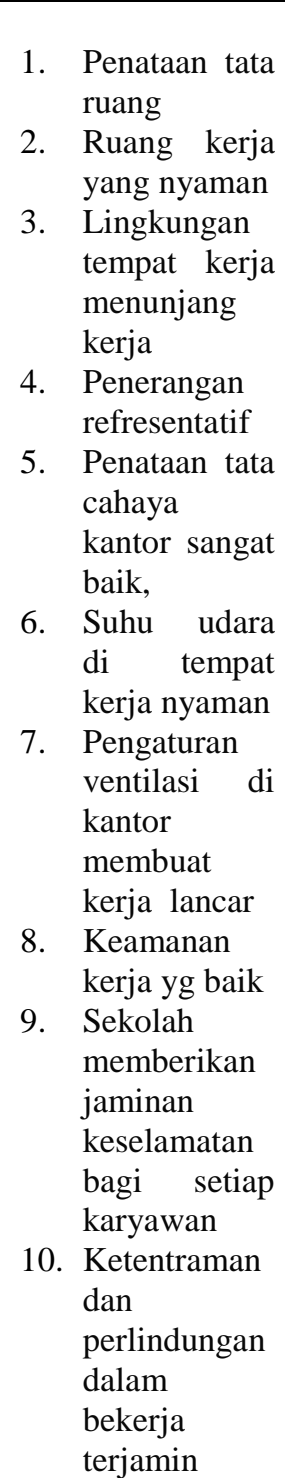 & $\begin{array}{l}\text { Rating } \\
\text { Scale } \\
\begin{aligned} 4=\mathrm{SS} \\
3=\mathrm{S} \\
2=\mathrm{TS} \\
1=\mathrm{STS}\end{aligned}\end{array}$ \\
\hline 2. & $\begin{array}{c}\text { Kepuasan } \\
\text { Kerja } \\
\text { (Y) }\end{array}$ & $\begin{array}{l}\text { Hasil dari persepsi } \\
\text { karyawan } \\
\text { mengenai } \\
\text { seberapa baik } \\
\text { pekerjaan } \\
\text { mereka } \\
\text { memberikan }\end{array}$ & $\begin{array}{l}\text { 1. Pekerjaan itu } \\
\text { sendiri }\end{array}$ & $\begin{array}{l}\text { 1.Sejauh mana } \\
\text { pekerjaan } \\
\text { menarik } \\
\text { 2.Kesempatan } \\
\text { belajar } \\
\text { 3.Kesempatan } \\
\text { menerima }\end{array}$ & $\begin{array}{l}4=\mathrm{SS} \\
3=\mathrm{S} \\
2=\mathrm{TS} \\
1=\mathrm{STS}\end{array}$ \\
\hline
\end{tabular}




\begin{tabular}{|c|c|c|c|c|c|}
\hline & & $\begin{array}{l}\text { hal yang dinilai } \\
\text { penting } \\
\text { (Luthan,2006) }\end{array}$ & $\begin{array}{l}\text { 2. Gaji } \\
\text { 3. Pengawasan } \\
\text { 4. Rekan }\end{array}$ & $\begin{array}{l}\text { tanggung } \\
\text { jawab } \\
\text { 4.Jumlah yang } \\
\text { diterima apakah } \\
\text { sesuai } \\
\text { 5.Adanya } \\
\text { tunjangan } \\
\text { sertifikasi guru } \\
\text { 6.Kemampuan } \\
\text { pimpinan } \\
\text { menyediakan } \\
\text { bantuan teknis } \\
\text { 7.Dukungan } \\
\text { perilaku dari } \\
\text { pimpinan } \\
\text { 8.Sejauh mana } \\
\text { rekan mendu } \\
\text { kung } \\
\text { pekerjaan } \\
\text { 9.Komunikasi } \\
\text { yang baik } \\
\text { antar sesama } \\
\text { karyawan }\end{array}$ & \\
\hline 3. & $\begin{array}{r}\text { Motivasi } \\
\text { kerja }\end{array}$ & $\begin{array}{l}\text { Motivasi kerja } \\
\text { didefinisikan } \\
\text { sebagai sesuatu } \\
\text { yang } \\
\text { menimbulkan } \\
\text { semangat atau } \\
\text { dorongan kerja. } \\
\text { (As'ad, 2006) }\end{array}$ & $\begin{array}{l}\text { 1. Intrinsik } \\
\text { 2. Ekstrinsik }\end{array}$ & $\begin{array}{l}\text { 1. Cita-cita } \\
\text { 2. Pendidikan } \\
\text { 3. Sikap } \\
\text { 4. Keluarga } \\
\text { 5. Teman } \\
\text { 6. Program } \\
\text { pendidikan }\end{array}$ & $\begin{array}{l}4=\mathrm{SS} \\
3=\mathrm{S} \\
2=\mathrm{TS} \\
1=\mathrm{STS}\end{array}$ \\
\hline 4. & $\begin{array}{l}\text { erja Guru } \\
\text { Z ) }\end{array}$ & $\begin{array}{l}\text { Penilaian Kinerja } \\
\text { Guru adalah } \\
\text { penilaian yang } \\
\text { dilakukan } \\
\text { setiap butir } \\
\text { kegiatan tugas } \\
\text { utama guru } \\
\text { dalam rangka } \\
\text { pembinaan } \\
\text { karier, } \\
\text { kepangkatan, } \\
\text { dan jabatannya } \\
\text { (Permendiknas No. } \\
\text { 41 Tahun 2007 } \\
\text { tentang } \\
\text { Penilaian } \\
\text { Kinerja Guru ) }\end{array}$ & $\begin{array}{l}\text { a.Merencanakan } \\
\text { Pembelajaran } \\
\\
\text { b.Melaksanaka } \\
\text { Kegiatan Pem } \\
\text { Belajaran } \\
\\
\text { c.Menilai Hasil } \\
\text { Belajar }\end{array}$ & \begin{tabular}{l}
\multicolumn{1}{|c}{ 1.Tujuan } \\
Pembelajaran \\
1.Materi Ajar \\
2.MetodePngjrn \\
3.Sumber Bljr \\
4.Penilaian hsl \\
belajar \\
5.Kegiatan Pegll \\
Kelas \\
6.Penggunaan \\
Media, sbr bljr \\
7.Penggunaan \\
Mtd \&strategi \\
pembelajaran \\
8.Tngkt Ktcpain \\
Tuj. pbljaran \\
9.Proses pbljr yg \\
dilakukan \\
10.Kemajuan \\
Prestasi yg \\
dicapai pesert \\
didik.
\end{tabular} & \\
\hline
\end{tabular}




\section{Analisis Data}

Persamaan I

Tabel 2

Hasil Analisis Regresi Linier Berganda

Coefficients

\begin{tabular}{|c|c|c|c|c|c|}
\hline \multirow[t]{2}{*}{ Model } & \multicolumn{2}{|c|}{$\begin{array}{r}\text { Unstandardized } \\
\text { Coefficients }\end{array}$} & \multirow{2}{*}{$\begin{array}{l}\text { Standardize } \\
\text { Coefficients } \\
\text { Beta }\end{array}$} & \multirow[t]{2}{*}{$\mathrm{t}$} & \multirow[t]{2}{*}{ Siq } \\
\hline & $\mathrm{B}$ & $\begin{array}{l}\text { Std } \\
\text { Error }\end{array}$ & & & \\
\hline (Contant) & 9,017 & 4,599 & & 1,961 & ,054 \\
\hline X1 Lingker & ,272 & ,079 & ,297 & 3,434 & ,001 \\
\hline X2 Kepuker & ,512 & ,072 & 618 & 7,144 & 000 \\
\hline
\end{tabular}

\section{a. Dependent Variable : Y Motivasi}

Berdasar hasil analisis regresi linier berganda yang diperoleh maka dibuat persamaan berganda sebagai berikut :

$$
\begin{aligned}
& Y=\beta_{1} \cdot X_{1}+\beta_{2} \cdot X_{2} \\
& Y=0,297 X_{1}+0,618 X_{2}
\end{aligned}
$$

Dimana: $\quad \mathrm{Y}=$ Motivasi

$\mathrm{X} 1$ = Lingkungan Keja

$\mathrm{X} 2=$ Kepuasan Kerja

$\beta_{1}, \beta_{2}=$ Koefisien pengaruh

Persamaan Linier Berganda tersebut dapat disimpulkan :

1. Koefisien regresi menunjukkan bahwa variable Lingkungan Kerja memiliki nilai beta positif 0,297. Hal ini menunjukkan bahwa semakin baik lingkungan kerja yang dimiliki semakin meningkatkan motivasi kerja

2. Koefisien regresi menunjukkan bahwa variable kepuasan kerja memiliki nilai beta positif sebesar 0,618 Hal ini menunjukkan bahwa semakin baik kepuasan akan meningkatkan motivasi kerja

\section{Persamaan II}

Analisis regresi dalam penelitian ini digunakan untuk mengetahui pengaruh lingkungan kerja, kepuasan kerja dan motivasi terhadap kinerja guru, diperoleh hasil regresi sebagai berikut : 
Tabel 3

Hasil Analisis Regresi Linier Berganda

Coefficients $^{\mathrm{a}}$

\begin{tabular}{|l|c|r|c|c|c|}
\hline \multirow{2}{*}{ Model } & \multicolumn{2}{|c|}{$\begin{array}{c}\text { Unstandardized } \\
\text { Coefficients }\end{array}$} & $\begin{array}{c}\text { Standardized } \\
\text { Coefficie } \\
\text { nts }\end{array}$ & $t$ & \multicolumn{2}{|c|}{ Siq } \\
\cline { 2 - 5 } & B & $\begin{array}{c}\text { Std } \\
\text { Error }\end{array}$ & Beta & & \\
\hline (Contant ) & $-6,042$ & 5,709 & & $-1,058$ &, 294 \\
X1 Lingker &, 513 &, 104 &, 339 & 4,930 &, 000 \\
X2 Kepuker &, 500 &, 117 &, 364 & 4,274 &, 000 \\
Y Motivasi &, 604 &, 154 &, 365 & 3,918 &, 000 \\
\hline
\end{tabular}

a. Dependent Variable : $Z$. Kinerja

$$
\begin{aligned}
& Z=\beta_{1} . . X+\beta_{2} . X_{2}+\beta_{3} . Y \\
& Z=0,339 X_{1}+0,364 X_{2}+0,365 Y \\
& \text { Dimana } \quad=Z \quad=\text { Kinerja } \\
& \mathrm{Y}=\text { Motivasi Kerja } \\
& \mathrm{X} 1=\text { Lingkungan Kerja } \\
& \mathrm{X} 2=\text { Kepuasan Kerja } \\
& \beta_{1}, \beta_{2}, \beta_{3}=\text { Koefisien pengaruh }
\end{aligned}
$$

Persamaan linier berganda tersebut dapat disimpulkan :

1. Koefisien regresi menunjukkan bahwa variable Lingkungan Kerja memiliki nilai beta sebesar positif 0,339. Hal ini menunjukkan bahwa semakin baik Lingkungan Kerja yang dimiliki akan meningkatkan kinerja guru.

2 . Koefisien regresi menunjukkan bahwa variable Kepuasan Kerja memiliki nilai beta Positif sebesar 0,34. Hal ini menunjukkan bahwa semakin baik yang dimiliki maka semakin meningkatkan kinerja guru.

3 . Koefisien regresi menunjukkan bahwa motivasi memiliki beta positif sebesar 0,365. Hal ini menunjukkan bahwa semakin tinggi motivasi kerja akan semakin meningkatkan kinerja guru. 


\section{Uji Model}

\section{Uji Model Persamaan I}

\section{Uji Anova ( F-test )}

Uji Anova atau uji $\mathrm{F}$ adalah uji statistik yang fungsinya untuk mengetahui apakah variabel independen lingkungan kerja dan kepuasan kerja merupakan model persamaan yang tepat untuk mengukur perubahan variabel motivasi. Dari olah data diperoleh hasil sebagai berikut :

\section{Tabel 4}

Hasil Uji Anova ${ }^{a}$

\begin{tabular}{|c|c|r|r|r|r|}
\hline Model & \multicolumn{1}{|c|}{$\begin{array}{c}\text { Sum of } \\
\text { Squares }\end{array}$} & Df & $\begin{array}{c}\text { Mean } \\
\text { Square }\end{array}$ & F & Sig \\
\hline Regression & 2510,249 & 2 & 1255,125 & 47,047 &, $000 \mathrm{a}$ \\
& 1627,360 & 61 & 26,678 & & \\
Residual & 4137,609 & 63 & & & \\
Total & & & & & \\
\hline
\end{tabular}

a. Predictors: (Contant), X2.Kepuasan, X1.Lingkungan

b. Dependent Variabel : Y.Motivasi

Pengujian pada tabel tersebut dapat disimpulkan sebagai berikut: Data di atas menunjukkan bahwa F hitung sebesar 47,047 dengan nilai Sig 0,000 $<0,05$. Variabel lingkungan kerja ( X1 ) dan kepuasan kerja ( X2 ) merupakan variabel yang baik dan tepat ( Fit ) untuk mengukur perubahan dalam variabel motivasi ( $\mathrm{Y}$ ), sehingga membentuk persamaan yang fit

\section{Uji Koefisien Determinasi ( $\mathbf{U j j}^{\mathbf{2}} \mathbf{R}^{2}$ )}

Koefisien determinasi atau adjusted $R$ square digunakan untuk mengetahui seberapa pengaruh variabel bebas (indevedent variable ). Hasil analisis diperoleh nilai koefisien determinan seperti berikut:

\section{Tabel 5}

Hasil Analisis Koefisien Determinasi

\begin{tabular}{|l|c|c|c|c|}
\hline Model & $\mathrm{R}$ & $\begin{array}{c}\mathrm{R} \\
\text { Square }\end{array}$ & $\begin{array}{r}\text { Adjusted R } \\
\text { Square }\end{array}$ & $\begin{array}{c}\text { Std.Error of the } \\
\text { Estimate }\end{array}$ \\
\hline 1 & & & & \\
&, $779^{\mathrm{a}}$ &, 607 &, 594 & 5,16508 \\
\hline
\end{tabular}

a. Predictors : (Constant), X2 Kepuasan, X1.Lingkungan 
Dari tabel tersebut diatas dapat disimpukan bahwa, Hasil perhitungan estimasi regresi diperoleh nilai koefisien determinasi (Adjusted $R$ Square) sebesar 0,594 atau 59,4\% perubahan pada variabel dependen motivasi kerja ( Y ) dapat dijelaskan oleh perubahan dalam variabel indevenden lingkungan kerja (X1) dan kepuasan kerja (X2), sedangkan sisanya sebesar 40,6\% diterangkan oleh variabel yang tidak diajukan atau dijelaskan dalam model penelitian ini.

\section{Uji Model Persamaan II}

\section{Uji Anova ( F-test )}

Uji Anova atau uji $\mathrm{F}$ adalah uji statistik yang fungsinya untuk mengetahui apakah variabel independen lingkungan kerja, kepuasan kerja dan motivasi kerja merupakan model persamaan yang tepat untuk mengukur perubahan variabel dependennya yaitu kinerja guru. Dari olah data diperoleh hasil sebagai berikut :

Tabel 6

Hasil Uji Anova ${ }^{b}$

\begin{tabular}{|l|c|c|c|c|c|}
\hline Model & $\begin{array}{c}\text { Sum of } \\
\text { Squares }\end{array}$ & df & Mean Square & F & Sig. \\
\hline Regression & 9031,799 & 3 & 3010,600 & &, 000 \\
Residual & 2320,310 & 60 & 38,672 & 77,850 &, $000^{\mathrm{a}}$ \\
Total & 11352,109 & 63 & & 31,4 & \\
\hline
\end{tabular}

a. Predictor : Contant) Y, Motivasi, X2 Lingkungan X1 Kepuasan

b. Dependen Variable : $Z$. Kinerja Guru

Pengujian pada tersebut diatas dapat disimpulkan sebagai berikut : Data di atas menunjukkan bahwa $\mathrm{F}$ hitung sebesar 77,850 dengan nilai sig $0,000<0,05$. Variabel lingkungan kerja (X1), kepuasan kerja (X2) dan motivasi ( Y ) merupakan variabel yang baik dan (fit) untuk mengukur perubahan dalam variabel kinerja guru ( $\mathrm{Z}$ ) sehingga nenbentuk persamaan yang fit.

\section{Uji Koefisien Determinasi ( Uji R $\mathbf{R}^{2}$ )}

Koefisien determinasi atau adjusted $R$ Square digunakan untuk mengetahui seberapa pengaruh variabel bebas ( devendent variable ). Hasil analisis diperoleh nilai koefisien determinasi sebagai berikut : 
Tabel 7

Hasil Analisis Koefisien Determinasi

\begin{tabular}{|l|c|c|c|c|}
\hline Model & $\mathrm{R}$ & $\begin{array}{c}\mathrm{R} \\
\text { Square }\end{array}$ & $\begin{array}{c}\text { Adjusted R } \\
\text { Square }\end{array}$ & $\begin{array}{c}\text { Std Error of } \\
\text { The } \\
\text { Estimate }\end{array}$ \\
\hline 1 &, $892^{\mathrm{a}}$ &, 796 &, 785 & 6,21867 \\
\hline
\end{tabular}

a. Predictors : (Contant), Y Motivasi, X2 Kepuasan, X1 Lingkungan.

Dari tabel tersebut diatas dapat disimpulkan bahwa hasil perhitungan estimasi regresi diperoleh nilai koefisien determinasi (Adjusted $R$ Square) sebesar 0,785 atau 78,5\% perubahan pada variabel dependen kinerja guru ( $\mathrm{Z}$ ) dapat dijelaskan oleh perubahan dalam variabel indevenden lingkungan kerja( X1), kepuasan kerja ( X2 ) serta motivasi kerja( Y ), sedangkan sisanya sebesar 21,5\% diterangkan oleh variabel lain yang tidak diajukan atau dijelaskan dalam model penelitian ini.

\section{Pengujian Hipotesis}

\section{Uji t ( pengaruh parsial )}

Uji parsial digunakan untuk menguji hipotesis adanya pengaruh variabel independen terhadap variabel dependen secara sendiri-sendiri. Dengan taraf siqnifikansi $\mathrm{a}=0,05$

1. Pengujian hipotesis pertama

Menguji pengaruh lingkungan kerja terhadap motivasi kerja. Diperoleh nilai koefisien beta positif sebesar 0,297 dan nilai siqnifikansi sebesar 0,001 < dari 0,05. Hal ini mengindikasikan hipotesis pertama diterima. Artinya lingkungan kerja berpengaruh secara positif dan siqnifikan terhadap motivasi kerja.

2. Pengujian hipotesis kedua

Menguji pengaruh kepuasan kerja terhadap motivasi kerja. Diperoleh koefisien beta positif sebesar 0,618 dengan nilai siqnifikansi sebesar 0,000 < 0,05, hal ini mengindikasi hipotesis kedua diterima. Artinya kepuasan kerja berpengaruh secara siqnifikan terhadap motivasi kerja.

3. Pengujian hipotesis ketiga

Menguji pengaruh motivasi kerja terhadap kinerja guru. Diperoleh koefisien beta positif sebesar 0,365 dengan nilai siqnifikansi sebesar $0,000<0,05$. Hal 
ini mengindikasikan hipotesis ketiga diterima. Artinya motivasi kerja berpengaruh terhadap kinerja guru.

4. Pengujian hipotesis kempat

Menguji pengaruh lingkungan kerja terhadap kinerja guru. Diperolah koefisien beta positif sebesar 0,339 dengan nilai siqnifikansi sebesar 0,000 < 0,05. Hal ini mengindikasikan hipotesis keempat diterima. Artinya lingkungan kerja berpengaruh secara positif dan siqnifikan terhadap kinerja guru.

5. Pengujian hipotesis kelima

Menguji pengaruh kepuasan kerja terhadap kinerja guru. Diperoleh koefisien beta positif sebesar 0,364 dengan nilai siqnifikansi sebesar $0,000<$ dari 0,05 . Hal ini mengindikasikan hipotesis kelima diterima. Artinya kepuasan kerja mempunyai pengaruh terhadap kinerja guru.

\section{Uji Efek Mediasi}

\section{Hasil Uji mediasi motivasi kerja dalam pengaruh lingkungan kerja terhadap} kinerja guru.

Pada hasil uji pengaruh lingkungan kerja terhadap kinerja guru dimediasi motivasi kerja dapat dinyatakan pada gambar sebagai berikut :

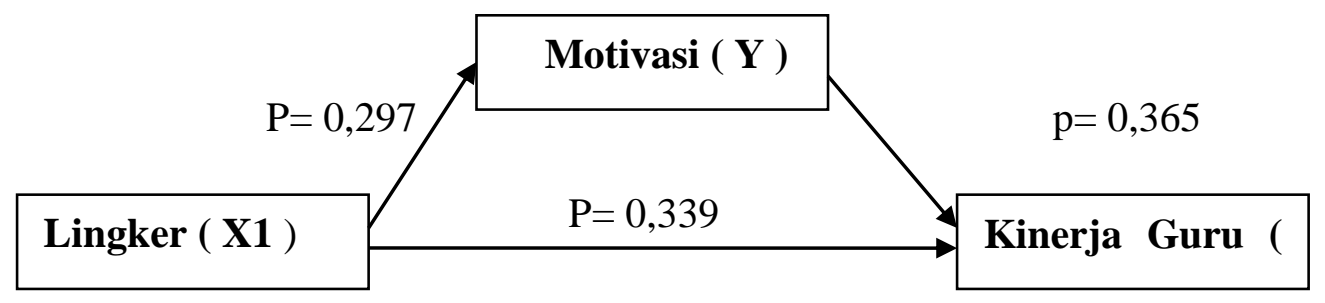

Gambar 2

Hasil pengujian :

Hubungan Langsung $p=0,339$

Hubungan Tidak Langsung 0,297 x 0,365 =0,108

Karena Hubungan langsung ( 0,339 ) > dari Hubungan Tidak Langsung (0,108) maka tidak ada mediasi. Lingkungan kerja lebih berdampak secara langsung memperngaruhi kinerja guru, dari pada melalui motivasi. Hasil Uji 
Mediasi motivasi dalam pengaruh kepuasan kerja terhadap kinerja guru dimediasi motivasi dapat dinyatakan pada gambar sebagai berikut :

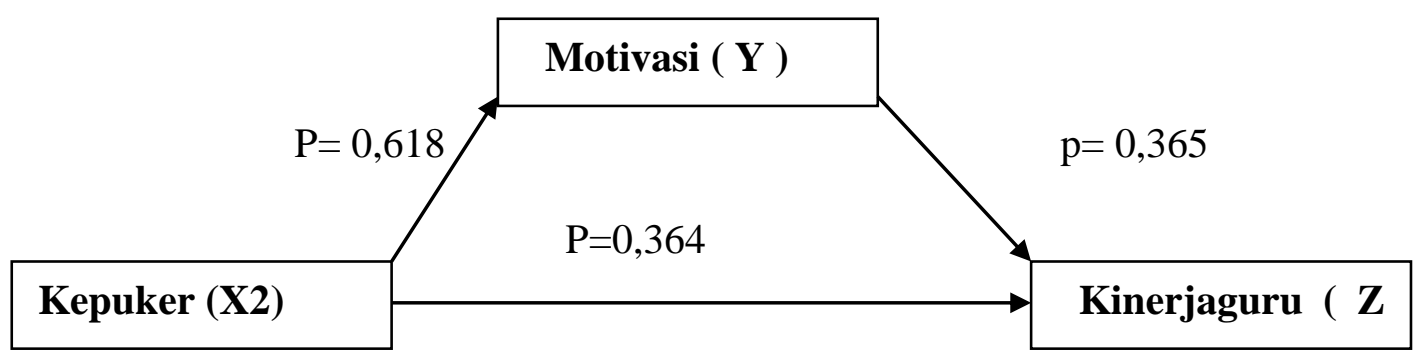

\section{Gambar 3}

Hasil Pengujian :

Hubungan Langsung $p=0,364$

Hubungan Tidak Langsung $0,618 \times 0,365=0,226$

Karena Hubungan Langsung $(0,364)>$ dari hubungan tak langsung $(0,226)$, maka tidak ada mediasi, kepuasan kerja lebih berdampak secara langsung berpengaruh pada kinerja guru dari pada motivasi

\section{KESIMPULAN DAN SARAN}

\section{Kesimpulan}

Penelitian ini menghasilkan kesimpulan sebagai berikut:

a. Lingkungan kerja berpengaruh terhadap motivasi kerja guru, artinya semakin baik kondisi lingkungan kerja bagi guru disekolah maka semakin meningkatkan motivasi kerja bagi guru.

b. Kepuasan kerja berpengaruh terhadap motivasi kerja guru, artinya guru yang merasa puas dalam melaksanakan tugas dan kewajibannya serta dipenuhi apa yang menjadi hak dan kewajibannya para guru, dengan sendirinya akan memotivasi kerja

c. Motivasi kerja berpengaruh terhadap kinerja guru, artinya guru yang memiliki motivasi kerja yang baik maka cenderung akan meningkaatkan kinerja guru disekolah.

d. Lingkungan kerja berpengaruh terhadap kinerja guru, artinya semakin baik lingkungan kerja disuatu sekolah cenderung akan meningkatkan kinerja guru disekolah. 
e. Kepuasan kerja berpengaruh terhadap kinerja guru,artinya manakala hak-hak guru dan kewajiban guru dipenuhi dengan sebaik-baiknya dengan sendirinya akan meningkatkan kualitas kinerja guru

f. Lingkungan kerja berpengaruh secara langsung terhadap kinerja guru, artinya tidak dimediasi oleh variabel motivasi kerja

g. Kepuasan kerja berpengaruh secara langsung terhapap kenerja guru disekolah, artinya variabel motivasi kerja tidak memediasi variabel kepuasan kerja terhadap variabel kinerja guru.

\section{Saran}

a. Pihak sekolah harus benar-benar memperhatikan kondisi dan lingkungan kerja guru disekolah, dengan pertimbangan agar semua pihak ikut bertanggung jawab membantu untuk menjaga kondisi lingkungan kerja bagi guru disekolah dengan harapan guru selalu memiliki motivasi kerja yang baik dan selalu meningkatkan kinerjanya secara maksimal.

b. Kepuasan kerja mempengaruhi kinerja guru, oleh karenanya bagaimana pihak lembaga Pembina dan pengelola pendidikan di SMK Ma'arif agar bisa meprioritaskan apa yang menjadi hak-hak seorang guru dilingkungan sekolah dan apa yang menjadi kewajiban seorang guru dengan harapan terjaga motivasi kerja guru dengan baik yang berimbas pada peningkatkan kinerja guru

c .Sekolah harus berusaha untuk membuat kondisi sekolah secara sehat dan transparansi serta obyektif diberbagai hal, dengan harapan guru akan memiliki kepercayaan yang mutlak terhadap beberapa kebijakan dari lembaga maupun pimpinan sekolah yang berimbas pada motivasi yang tinggi guna meningkatkan kinerja guru secara maksimal. 


\section{DAFTAR PUSTAKA}

As’ad,M (2009), Psikologi Indstri, Yogyakarta: Liberty

Azeem, Sayed Muhammad, (2010), Job Satisfaction and Organizationale and Commitment Among Employees in Sultanate of Oman, Scientific Researc, Vol 1 , pp $295-299$.

Davis,K dan Newstron (2009), Perilaku Organisasi, Jakarta: Erlangga.

Daryanto, (2013), Standar Kompetensi dan Penilaian Kinerja Guru Profesional, Yogyakarta, Gava Media

Khoerul, Umam, (2010), Perilaku Organisasi, Bandung, CV Pustaka Setia.

Luthans, Freed (2009), Perilaku Organisasi, Yogyakarta : Andi Mahmud

Natawijaya, H (2009), Motivasi Kerja Pegawai, Jakarta : Angkasa

Nitisemito, Alex S (2011), Manajemen Personalia, Manajemen Sumber Daya Manusia, Jakarta, Ghalia Indonesia

Permendiknas Nomor 41 Tahun 2007, Tentang Standar Proses Untuk Satuan Pendidikan Dasar dan Menengah

Peraturan Pemerintah Nomor 74 Tahun 2007, Tentang Guru

Undang-Undang RI Nomor 14 Tahun 2005, tentang Guru dan Dosen

Umar,Husain .( 2009), Manajemen Sumber Daya Manusia, Jakarta, Gramedia Pusaka Utama.

Safri,M, (2007), Manajemen Sumber Daya Manusia, Jakarta: Bumi Aksara

Sule, ET, dan Saefullah,K, (2007), P engantar Manajemen, Jakarta: Kencana

Sedarmayanti, (2009), Sumber Daya Manusia dan Produktifitas Kerja, Bandung : Ilham Jaya

Winardi,( 2009), Motivasi dan Pemotivasian dalam Manajemen, Jakarta: PT Raja Grafindo Persada

Sihombing, (2009), Manajemen Sumber Daya Manusia, Jakarta : Balai Pustaka

Sugiyono, (2006), Statistika untuk Penelitian, Bandung, CV Alfabeta.

Suharsimi Arikunto, (2008), Prosedur Penelitian: Suatu Pendekatan Praktek, Rineka Cipta, Jakarta.

Pengaruh Lingkungan Kerja Dan Kepuasan Kerja Terhadap Kinerja Dimediasi Motivasi Kerja Pada Guru- Guru SMK Ma'arif Comal Pemalang. (Samtono) 